\title{
KONTRIBUSI KEPEMIMPINAN KEPALA MADRASAH TERHADAP KINERJA GURU MADRASAH ALIYAH SWASTA SE-KECAMATAN LINTAU BUO UTARA
}

\author{
Andra Endi \\ Guru SDN Lintau Buo, \\ Koresponden: J alan Kesehatan I No.18 J orong Kota Tepi Selo Kecamatan Lintau Buo Utara, \\ e-mail: andra.endi@gmail.com
}

\begin{abstract}
Contribution Leadership Head of Madrasah Aliyah to Teacher Performance of Madrasah Aliyah Sawasta in District Lintau Buo Utara. The Contribution of School Principal's Leadership and The Performance of Private Islamic Senior High School Teacher's at Lintau Buo Utara.

On the basis of a preliminary field observation, the reseacher noticed that Private Islamic Senior High School Teachers' performance at Lintau Buo Utara district was relatively low. It was presumed that the teachers' low performance was caused by the ineffective leadership of the school

The purpose of this research was to reveal how extend the contribution of the school principal's leadership of Private Islamic Senior High School at Lintau Buo Utara District. There were three hypotheses to be tested : 1) the school principal's leadership contributed significantly toward the teachers' performance; 2) simultaneously, the school principal's leadership of Private Islamic Senior High School at Lintau Buo Utara District.

The result of data analyses show that the school principal's leadership contributed significantly $(24.1 \%)$ toward the teachers' performance toward the teachers' performance.
\end{abstract}

Kata Kunci: Kontribusi, kepemimpinan, kinerja guru

\section{PENDAHULUAN}

Sebagai pemimpin memegang peranan yang sangat penting Kepemimpinan kepala madrasah harus mampu mempengaruhi bawahan agar dapat melaksanakan tugasnya dengan baik, pemimpin juga harus bisa dekat dengan bawahannya, agar bawahannya merasa tenang menerima bimbingan dan arahan oleh atasannya. (Mulyasa, 2003: 103)
Dalam pelaksanaan, kepala madrasah terlihat masih belum maksimal dalam kinerjanya, misalnya untuk pemeriksaan perangkat ajar, supervisi kegiatan mengajar di dalam kelas, serta evaluasi kegiatan akhir pembelajaran yang dilakukan oleh guru. Untuk penerapan kedisiplinan, kepala sekolah belum menerapkan disiplin untuk guru, misalnya ketika guru datang terlambat, belum ada tindak lanjut dari pelanggaran disiplin. 
Tujuan dari penelitian ini adalah untuk mengungkap seberapa jauh kontribusi kepemimpinan kepala Madrasah terhadap kinerja guru dan Kontribusi kepemimpinan kepala Madrasah dan motivasi kerja guru berkontribusi terhadap kinerja guru Madrasah Aliyah Swasta (MAS) sekecamatan Lintau Buo Utara .

Penelitian ini diharapkan bergunan bagi kepala Madrasah khususnya kepala Madrasah Aliyah Swasta (MAS) sekecamatan Lintau Buo Utara sebagai bahan masukan untuk pembinaan kinerja guru. Bagi guru, khususnya guru Madrasah Aliyah Swasta (MAS) se-kecamatan Lintau Buo Utara sebagai umpan balik tentang kinerjanya pada masa lalu dan perbaikan pada masa mendatang.

Subyek dari penelitian merupakan keseluruhan populasi yang menjadi target untuk diteliti. Populasi adalah totalitas dari semua obyek atau individu yang memiliki karakteristik tertentu, jelas dan lengkap yang akan diteliti, atau dengan kata lain populasi adalah seluruh obyek atau individu yang mempunyai karakteristik yang sama yang menjadi sasaran penelitian. Dalam penelitian ini yang menjadi subyek penelitian adalah seluruh guru tetap MAS Se-Kecamatan Lintau Buo Utara tahun pelajaran 2012/2013 yang berada di bawah naungan Kemenag Kabupaten Tanah Datar. Subyek penelitian berjumlah 67 orang.

Untuk memudahkan penelitian ini, maka perlu diambil sebagian saja dari jumlah keseluruhan populasi yang biasa disebut sampel. Sampel adalah bagian dari populasi. Hal senada diungkapkan Hasan bahwa sampel adalah bagian dari populasi yang diambil melalui cara-cara tertentu yang memiliki karakteristik tertentu, jelas dan lengkap yang dianggap bisa mewakili populasi. Tidak ada aturan yang tegas tentang jumlah sampel yang dipersyaratkan untuk suatu penelitian dari populasi yang tersedia, namun demikian Suharsimi Arikunto mengatakan bahwa apabila subyek penelitian kurang dari 100, lebih baik diambil semua sehingga merupakan penelitian populasi. Selanjutnya jika jumlah subyeknya besar dapat diambil antara 10\%-15\% atau 20\%-25\% dan atau lebih.

Instrumen dalam penelitian ini adalah angket yang merupakan daftar pertanyaan yang diajukan kepada responden untuk dijawab. Pada pengambilan data dengan instrumen angket, penentuan skor item pernyataan terhadap masalah yang diteliti dilakukan dengan pengukuran item yang terdiri dari empat opsi yang mempunyai gradasi dari positif sampai negatif.

Dalam penelitian ini pengumpulan data dilakukan dengan menggunakan instrumen angket, untuk memperoleh data tentang kontribusi kepemimpinan kepala madrasah dan motivasi kerja guru dengan kinerja guru. Langkah-langkah penyusunan angket yang dilakukan sebagai berikut: Kisi-kisi disusun dalam bentuk matrik yang di dalamnya 
tertuang konsep perilaku kepemimpinan kepala madrasah, keterampilan manajerial kepala madrasah, dan kinerja guru. Konsep ini dijabarkan ke dalam variabel dan indikator, masing-masing indikator terwakili oleh item-item angket sebagai alat ukur. Setelah kisi-kisi angket dibuat barulah menyusun item-item angket.Item angket disusun berdasarkan kisi-kisi yang telah dibuat mengacu pada tiga variabel yang digunakan, yaitu kontribusi kepemimpinan kepala madrasah, motivasi kerja guru, dan kinerja guru.

Instrumen yang digunakan untuk mengukur masing-masing variabel terdiri dari 35 item soal untuk kepemimpinan, 25 item soal untuk motivasi kerja guru, dan 35 item soal untuk kinerja guru yang disusun oleh peneliti. Cara yang digunakan untuk menentukan skor dalam penelitian ini dengan menggunakan skala Likert, yaitu "suatu skala yang digunakan untuk mengukur sikap, pendapat, persepsi seseorang atau sekelompok orang tentang fenomina sosial". Jawaban dari setiap item instrumen tersebut memiliki gradasi dari positif sampai negatif, yang berupa kata-kata seperti: Sangat sering (SS) skornya 5, Sering (S) skornya 4, Kadang kadang (KK) skornya 3, Jarang (J) skornya 2 dan Jarang sekali (JS) skornya 1 untuk pertanyaan positif nilainya 5, 4, 3, 2,1 dan untuk pertanyaan negatif skala nilainya $1,2,3,4,5$. Dalam pengukuran variabel penelitian, responden diminta untuk menyatakan persepsinya dengan memilih salah satu alternatif jawaban dalam skala satu sampai lima.

Adapun pengembangan instrumen untuk masing-masing variabel penelitian adalah sebagai berikut:Angket tentang kepemimpinan kepala madrasah terdapat tujuh sub variabel, yaitu: (1) kepala madrasah sebagai educator, (2) kepala madrasah sebagai manajer, (3) kepala madrasah sebagai administrator, (4) kepala madrasah sebagai supervisor, (5) kepala madrasah sebagai leader, (6) kepala madrasah sebagai inovator dan (7) kepala madrasah sebagai motivator. Dalam instrumen perilaku kepemimpinan ini terdapat 35 item pernyataan, sehingga skor total terendah adalah 35 (hasil perkalian antara 1 dengan banyaknya jumlah pernyataan 35 buah), dan skor total tertinggi adalah 175 (hasil perkalian antara 5 dengan banyaknya jumlah pernyataan 35 buah).

Angket tentang kinerja guru terdapat delapan sub variabel, yaitu: (1) penyusunan program, (2) pelaksanaan program, (3) pelaksanaan evaluasi, (4) analisis evaluasi, (5) perbaikan pengajaran, (6 kemampuan, (7) usaha yang dilakukan, dan (8) dukungan organisasi. Dalam instrumen kinerja guru ini terdapat 35 item pernyataan, sehingga skor total terendah adalah 35 (hasil perkalian antara 1 dengan banyaknya jumlah pernyataan 35 buah), dan skor total tertinggi adalah 175 (hasil perkalian antara dengan banyaknya jumlah pernyataan 35 buah). 
Pemberian skor angket diawali dengan pemberian kode terhadap jawaban responden. Pemberian kode atas jawaban responden dengan menggunakan kriteria berikut: sering sekali, sering, kadang-kadang, jarang sekali dan jarang. Besar skor masingmasing adalah: sering sekali dengan nilai 5 , sering dengan nilai 4, kadang-kadang 3, jarang 2 dan jarang sekali dengan nilai 1.

Dalam menentukan pilihan responden didasarkan pada kecenderungan yang sesuai dengan alternatif jawaban terhadap item yang bersangkutan, yaitu: (1) sering sekali, artinya kejadian/keadaan yang digambarkan pada item tersebut benar-benar sesuai dengan kenyataan dan selalu dilaksanakan, (2) sering, artinya kejadian/keadaan yang digambarkan pada item tersebut lebih banyak sesuai dengan kenyataan dari pada tidak, dan sering dilaksanakan, (3) kadang-kadang artinya kejadian/keadaan yang digambarkan pada item tersebut lebih banyak tidak sesuai dengan kenyataan dan sedikit dilaksanakan, (4) jarang, kejadian/keadaan yang digambarkan pada item tersebut benar-benar tidak sesuai dengan kenyataan yang ada dan jarang dilaksanakan, (5) jarang sekali adalah keadaan yang digambarkan pada item tersebut benar-banar jarang sekali untuk dilaksanakan.

Data penelitian ini berupa persepsi guru tentang perilaku kepemimpinan, keterampilan manajerial kepala madrasah dan kinerja guru. Kode-kode tersebut jika dijadikan data pada hakekatnya berskala ordinal. Menurut Sukardi, dalam suatu penelitian yang instrumennya berupa kuesioner di mana item pertanyaan/ pernyataan menggunakan skala ordinal yang telah diberi harga ekuevalen, maka skala tersebut dapat berubah menjadi skala interval. Artinya dalam item pertanyaan/ pernyataan apabila opsi jawabannya, misalnya: selalu, sering, kadang-kadang dan jarang tanpa diberi nilai/diangkakan, maka skala data dari opsi tersebut adalah ordinal, tetapi apabila opsi-opsi tersebut diberi nilai/diangkakan maka skala data dari opsi-opsi tersebut menjadi data interval. Misalnya sangat sering bernilai 5 , sering bernilai 4 dan seterusnya.

\section{PEMBAHASAN}

\section{Deskripsi Variabel Penelitian}

Deskripsi data dari hasil penelitian dimaksudkan untuk memberikan gambaran umum mengenai penyebaran atau distribusi data, baik yang berupa ukuran gejala sentral, ukuran letak maupun distribusi frekuensi. Data yang akan disajikan setelah diolah dari data mentah dengan menggunakan software SPSS 17.00.

Deskripsi data dikelompokkan menjadi tiga bagian yaitu: Kinerja guru (Y), Kepemimpinan kepala Madrasah $\left(\mathrm{X}_{1}\right)$, Motivasi kerja guru $\left(\mathrm{X}_{2}\right)$ dan Kinerja guru (Y). Jumlah guru MAS se-Kecamatan Lintau Buo Utara adalah sebanyak 67 orang dengan 
hasil perhitungan analisis statistik deskriptif masing-masing variabel diuraikan secara berurutan berikut ini:

\section{Variabel Kepemimpinan kepala Madrasah $\left(\mathrm{X}_{1}\right)$}

Untuk mengetahui hasil penelitian tentang Kepemimpinan kepala MAS seKecamatan Lintau Buo Utara, maka berikut disajikan distribusi frekuensi dari pengolahan data yang diperoleh frekuensi skor data penelitian tentang Kepemimpinan kepala Madrasah dengan rata-rata 105.39 , median 104.00, mode 105 dan standar deviasi 5.405 selanjutnya nilai minimum adalah 104 dan nilai maximum adalah 126

\section{Variabel Kinerja guru $(Y)$}

Untuk mengetahui hasil penelitian tentang Kinerja guru MAS se-Kecamatan Lintau Buo Utara, maka berikut disajikan distribusi frekuensi dari pengolahan data yang diperoleh data penelitian tentang MAS se-Kecamatan Lintau Buo Utara dengan ratarata 113 , median 117 , mode 116 dan standar deviasi 6.043 selanjutnya nilai minimum adalah 104 dan nilai maximum adalah 126

\section{Uji Hipotesis}

Untuk menguji hipotesis, yaitu terdapat kontribusi Kepemimpinan kepala Madrasah terhadap Kinerja guru maka uji hipotesis yang digunakan adalah secara parsial, diperoleh bahwa $r$ adalah 0,624 yaitu terdapat kontribusi yang cukup kuat positif antara Kepemimpinan kepala Madrasah dengan Kinerja guru dan nilai koefisien determinan atau $r$ square adalah 0,389 yang berarti bahwa kontribusi Kepemimpinan kepala Madrasah terhadap Kinerja guru sebesar 0.389 atau $38.90 \%$ atau sebesar $61.10 \%$ dipengaruhi oleh variabel lain, yang tidak termasuk dalam variabel yang diteliti. Kemudian kalau dilihat dari sifnifikansi model summary yaitu 0,000. Dimana angka ini menunjukkan bahwa Kepemimpinan kepala Madrasah mempunyai kontribusi yang signifikan terhadap kinerja guru ini disebabkan angka $\mathrm{t}_{\text {hitung }}(4.65)>$ dari $\mathrm{t}_{\text {tabe }}$ $(2,030)$ dan ini diperkuat dengan signifikan yang diperoleh dari pengolahan data yaitu kecil dari 5\%, maka penulis berkesimpulan bahwa Kepemimpinan kepala Madrasah mempunyai kontribusi yang berarti atau signifikan terhadap Kinerja guru. Artinya apabila baik Kepemimpinan kepala Madrasah yang dilakukan oleh MAS seKecamatan Lintau Buo Utara maka Kinerja guru tersebut akan semakin baik, dan begitu juga sebaliknya, jika Kepemimpinan kepala Madrasah menurun maka Kinerja guru itu juga akan menurun .

Dengan persamaan tersebut dapat dijelaskan bahwa setiap dinaikkan Kepemimpinan kepala Madrasah satu satuan maka Kinerja guru akan naik sebesar 0,697 atau koefisien regresinya adalah 0,697, sedangkan bila Kepemimpinan kepala Madrasah di asumsikan nol atau tidak ada maka Kinerja guru tetap akan ada sebesar konstanta yaitu 27.137 


\section{Temuan Penelitian}

Pada penelitian ini hasil perhitungan atau perolehan angka pengisian instrumen yang diberikan pada responden di dapatkan data dari setiap indikator dan dari setiap variabel maka dapat penulis kemukakan rata-rata pada masing-masing variabel, tingkat pencapain responden dan kategori perolehan sebagaimana pada tabel berikut :

Dari Tabel di atas dapat kita kemukakan beberapa temuan sebagai berikut: 1) Pada variabel Kinerja Guru taraf pencapaian responden (tcr) berkategori baik. Hal ini mengambarkan bahwa kinerja guru pada Madrasah Aliyah Swasta se- Kecamatan Lintau Buo Utara sudah cukup baik. 2) Pada variabel Kepemimpinan Kepala Madrasah dapat di lihat bahwa taraf pencapain responden responden belum baik karena masih tergolong dalam taraf cukup dan motivasi kerja yang baik, sehingga dapat terlihat pada data yang sudah diungkapkan dalam tabel di atas.

Seorang pemimpin yang ideal dalam pendidikan Islam harus memiliki prinsip-prinsip sebagai berikut: 1) Saling menghormati dan memuliakan Dalam konteks organisasi dan kepemimpinan seorang guru dalam pendidikan Islam, seorang guru hendaklah memandang anak/ peserta didik sama tanpa ada perbedaan anak dengan lainnya. Sekalipun mereka memiliki latar belakang yang berbeda. Hal tersebut hendaknya disikapi secara bijaksana dengan tetap memegang prinsip menghormati dan memuliakan sehingga tidak ada anak yang merasa dirugikan.2) Menyebarkan kasih sayang seorang pemimpin yang memiliki sifat kasih sayang akan dipandang sebagai panutan yang selalu memberikan perlindungan kepada pengikutnya. Pemimpin yang memiliki kasih sayang juga memberikan rasa aman kepada para pengikutnya. Semua tindakannya dilakukan atas dasar kasih sayang terhadap seluruh pengikutnya dan perkembangan organisasi yang dipimpinnya.3) Keadilan seorang pemimpin sering menjadi faktor yang menentukan kinerja dan motivasi seorang bawahan. Perlakuan yang tidak adil akan mendatangkan masalah yang lebih besar yang tidak hanya akan merugikan pemimpin secara individu tetapi pihak lainnya. Oleh karena itu, prinsip keadilan hendaknya dipandang sebagai titik pijakan yang paling penting dalam memimpin dan mengelola organisasi. 4) Berpegang pada akhlak yang utama yang berkaitan dengan pergaulan hidup diantara sesama manusia. Pemimpin yang lemah lembut akan dipandang sebagi orang yang santun dan tidak pernah meremehkan orang lain. Ketika menemukan kesalahan dari para pengikutnya, ia akan menegur karena hatihati dan tetap menghargai kehormatannya demikian juga halnya dengan seorang guru. Pemimpin yang mudah memaafkan bukanlah pemimpin yang lemah, justru sifat ini merupakan gambaran dari kekuatan untuk memahami kesalahan yang dilakukan peserta didik dalam batasan-batasan tertentu. 
5) Pemimpin ideal seorang guru dalam pendidikan Islam adalah peserta didik diberi kesempatan dalam mengemukakan pikiran dan perasaannya atau mengeluarkan pendapatnya selama dalam proses pembelajaran, guru menghargai pendapat peserta didik, guru tidak boleh mematikan aspirasi peserta didiknya.Pemimpin harus menepati janjinya agar tidak menghilangkan kepercayaan dari bawahannya, begitu juga di sekolah guru haruslah menepati janjinya kepada peserta didik karena janji itu adalah hutang yang harus dibayar. Janji disini seperti kedisiplinan, dam belajar dan mengajar, memberikan tugas dan kegiatan akademik lainnya.

Itulah beberapa prinsip kepemimpinan ideal seorang guru dalam pendidikan Islam yang dikehendaki di dalam kepemimpinan Islam, tidak hanya sesuai dengan ajaran Islam tetapi juga sejalan dengan aturanaturan kemanusian atau kehidupan sosial.

Dalam kepemimpinan di dalam Islam juga dibutuhkan motivasi, karena kunci keberhasilan sebuah proses kepemimpinan seorang guru dalam pendidikan Islam adalah motivasi, seorang pemimpin harus bisa memotivasi pendidik, peserta didik, serta orang-orang yang bekerja dan berjuang dengannya.

Kepemimpinan kepala madrasah berkontribusi terhadap kinerja guru, untuk menciptakan kinerja yang baik antara kepala madrasah dengan guru, maka diperlukan motivasi kerja dari seorang guru. Adapun motivasi kerja adalah kekuatan yang mendorong seseorang untuk melakukan kerja sehingga bersemangat, kesungguhan dan bertanggung jawab. Apabila seseorang telah memiliki motivasi kerja yang baik, maka semuanya akan berjalan dengan baik.

\section{PENUTUP}

Berdasarkan hasil penelitian yang telah dilakukan dapat dikemukakan beberapa kesimpulan sebagai berikut:

Terdapat kontribusi yang signifikan kepemimpinan kepala Madrasah terhadap kinerja guru Madrasah Aliyah Swasta seKecamatan Lintau Buo Utara kabupaten Tanah Datar dengan koefisien korelasi atau $r=0,624$ dan $r$ square $\left(r^{2}\right)$ sebesar 0,389, dimana besar kontribusi Kepemimpinan kepala Madrasah Aliyah Swasta seKecamatan Lintau Buo Utara kabupaten Tanah Datar adalah 0,697 yang dinyatakan dengan persamaan regresi yaitu :

$$
\mathrm{Y}=27.137+0,697 \mathrm{X}
$$

Terdapat kontribusi yang signifikan antara kepemimpinan kepala madrasah dan terhadap kinerja guru Madrasah Aliyah Swasta se-Kecamatan Lintau Buo Utara kabupaten Tanah Datar dengan koefisien korelasi atau $R=0,711$ dan $r$ square $\left(R^{2}\right)$ sebesar 0,505 , dimana dengan persamaan regresi yaitu:

$$
Y=14.502+0,354 X 2
$$


Berdasarkan temuan penelitian ini, maka peneliti mengemukakan beberapa saran sebagai rekomendasi kepada berbagai pihak sebagai berikut : Guru Madrasah Aliyah se- Kecamatan Lintau Buo Utara:

1) Hendaknya guru dapat meningkatkan kinerjanya karena kesejahteraan sebagai guru pada saat ini sudah meningkat, diharapkan bahwa guru dapat sebagai contoh dalam kehidupan peserta didik dan masyarakat.

2) Para guru Madrasah Aliyah se- Kecamatan Lintau Buo Utara diharapkan untuk dapat meningkatkan kinerjanya karena guru sebagai agen pembelajaran.

3) Kepala madrasah merupakan tenaga yang melakukan pembinaan atau supervise pembelajaran di madrasah.

4) Kepala madrasah diharapkan mampu membina dan membantu guru dalam memperbaiki kesalahan dalam proses pembelajaran.

5) Kepala madrasah diharapkan dapat meningkatkan kemampuannya dalam melakukan pembinaan dengan mengikuti pelatihan atau sesering mungkin mengikuti seminar-seminar yang berkaitan dengan pendidikan dalam rangka memperluas wawasan dan kemampuan.

6) Hendaknya kepala madrasah mampu berperan membantu dan merobah (to help dan to change) guru sehingga menjadi lebih baik dalam melakukan proses pembelajaran.
7) Kepada Dinas Pendidikan atau Kementeran Agama untuk dapat melakukan penambahan jumlah pengawas di masa yang akan datang sehingga mampu mencukupi kekurangan guru yang ada saat ini.

8) Kepada Kementerian Agama untuk dapat mengikut sertakan kepala madrasah yang ada di lingkungan Kementeran Agama untuk mengikuti pelatihan-pelatihan sehingga dapat meningkatkan kemampuan memimpin dalam menjalankan tugasnya.

9) Peneliti selanjutnya agar lebih meneruskan penelitian ini pada aspek-aspek yang lain yang juga mempengaruhi dan memberikan kontribusi terhadap kinerja guru yang belum terungkap dalam penelitian ini, sehingga penelitian lanjutan akan memperlengkap pengetahuan tentang keberhasilan kinerja guru dan dapat meningkatkan kemampuan guru di masa yang akan datang.

\section{KEPUSTAKAAN ACUAN}

Aan Komariah. 2006, Menuju Sekolah Efektif, Jakarta: PT Bumi Aksara

Dharma. 1991, Perilaku Dalam Organisasi, Jakarta Erlangga.

Gouzali. 2000, Managemen Sumber Daya Manusia, Jakarta: Djambatan.

Husen Umar. 2002, Metode Riset Komunikasi Organisasi, Jakarta: Gramedia. 
Iqbal Hasan. 2006, Analisis Data Penelitian Mulyasa. 2003, Menjadi Kepala Sekolah dengan Statistik, Jakarta: Bumi Aksara Profesional, Bandung: Remaja Rosdakarya Melayu SP Hasibuan. 2003, Managemen Ramayulis. 2002, Ilmu Pendidikan Islam, Sumber Daya Manusia, Jakarta: Bumi Jakarta: Kalam Mulia Aksara 